\title{
FACTORS INFLUENCING THE LATE DELIVERY OF PROJECTS IN STATE-OWNED ENTERPRISES: THE CASE OF ESKOM
}

\author{
L. Flepisi1* \& C. Mlambo²
}

\section{ARTICLE INFO}

\section{Article details}

Submitted by authors 28 Oct 2020

Accepted for publication 23 Sep 2021

Available online $14 \mathrm{Dec} 2021$

\section{Contact details}

Corresponding author

lubabalo@siyavuya.co.za

Author affiliations

1 Department of Management and Entrepreneurial Studies, Durban University of Technology, South Africa

2 Faculty of Management and Commerce, University of Fort Hare, South Africa

\section{ORCID® identifiers}

L. Flepisi

https://orcid.org/0000-0001-5666-6432

C. Mlambo

https://orcid.org/0000-0002-5808-5612

\section{DOI}

http://dx.doi.org/10.7166/32-4-2455

\section{ABSTRACT}

Delays in project completion by state-owned enterprises are a major concern and a threat to the South African economy. This study investigates both the internal and the external factors influencing the late delivery of projects in state-owned enterprises, with ESKOM as a case study. The research design was a survey questionnaire that was used to gather sufficient information. The study revealed key internal and external factors influencing the late delivery of projects in the state-owned enterprises, including the failure to update construction programmes, the late delivery of contractor-supplied materials, corruption, and political interference. In conclusion, we posit that, to ensure early project completion, the authorisation and empowerment of the project team is vitally important.

\section{OPSOMMING}

Vertragings in projekvoltooiing deur ondernemings in staatsbesit is ' $n$ ernstige bekommernis en bedreiging vir die Suid-Afrikaanse ekonomie. Hierdie studie ondersoek beide die interne en eksterne faktore wat die vertragings beïnvloed. ESKOM word as 'n gevallestudie voorgehou. ' $n$ Opname vraelys is gebruik om inligting in te samel. Die studie toon dat sleutel interne- en eksterne faktore die vertragings beïnvloed, insluitend die gebrek aan opgedateerde konstruksie programme, die laat aflewering van kontrakteurs se verskafde materiaal, korrupsie, en politieke inmenging. Die gevolgtrekking is dat die goedkeuring en bemagtiging van die projekspan krities belangrik is.

The late completion of projects is a problem faced by many institutions globally, in both developed and developing countries. The challenge of the late delivery of projects affects not only the construction sites of state-owned enterprises (SOEs), but also those of other organisations around the world. Ameh and Osegbo [1] state that the history of the construction industry globally reveals that most projects face significant time and cost overruns. This indicates that the challenge of the late delivery of projects requires full attention to ensure project success, because it gives rise to increasingly adversarial relationships, arbitrations, cash flow problems, and anxiety among project stakeholders [1].

Thus, there is a need to investigate the factors that hinder project success to ensure that such factors are fully addressed. According to Clements and Gido [2], the success of project objectives depends on the people, not on the procedures or techniques. This suggests that stakeholders play a critical role in ensuring the success of a project - that it is vitally important for them to be managed so that they can ensure that projects are delivered by the planned completion date. This can be achieved through project stakeholder management. This study seeks to investigate the internal and external factors influencing the late delivery of projects at Eskom, a state-owned enterprise, in order to prevent its reoccurrence.

Eskom Holdings SOC Limited is a power utility that generates, transmits and distributes around $95 \%$ of the electricity used by South African consumers [3]. Eskom was established in 1923, and its sole shareholder is the South African government. The company aims to ensure that there is sufficient affordable electricity 
for its customers. Eskom is faced with the challenge of not being able to provide an adequate supply of electricity to South African consumers owing to the growth in the number of customer connections to the national grid over the past few years. This places the security of supply at risk, and keeps Eskom from achieving its core strategy of ensuring the continuity of an electricity supply to consumers. Eskom has embarked on a capacity expansion programme, which includes the building of new power stations such as Medupi, Kusile, and Ingula [4]. The connection of these power stations to the grid in order to supply electricity is of critical importance to enable Eskom to provide sufficient electricity. In the case of the Medupi Power Station building project, for example, Eskom customers are concerned that the project has not been completed by the planned completion date (the first Medupi unit was scheduled to be completed by the end of 2012). The late delivery of that power station has resulted in Eskom not having enough capacity to supply the entire country, leading inevitably to load shedding [4]. This implies that every late delivery of a project has an impact on those who have an interest in the project.

\section{LITERATURE REVIEW}

\subsection{The concept of 'project management'}

\subsubsection{Project definition}

Gray and Larson [5] define a project as a unique time-consuming task that is created to meet the need of the customer and that is limited in terms of time, cost, and specification. In addition, a project is designed and implemented to produce a distinctive product, service, or outcome within a certain period of time. A project has a definite beginning and end [6]. According to Kohli and Chitkara ([7], a project can be defined as a unique product of high importance that is undertaken to meet certain requirements that are constrained by time, quality, and costs. The above-mentioned authors agree that a project is a planned sequence of tasks that are executed to create a special product or service to suit the needs of the customer. In addition, every project is time-bound by its nature. A project's completion date can therefore be regarded as one of its most important factors. Projects are intended to accomplish certain goals, and can be categorised into many sizes at different maturity levels. Although there is no standard classification of projects, the figure below indicates how projects can be grouped [7].

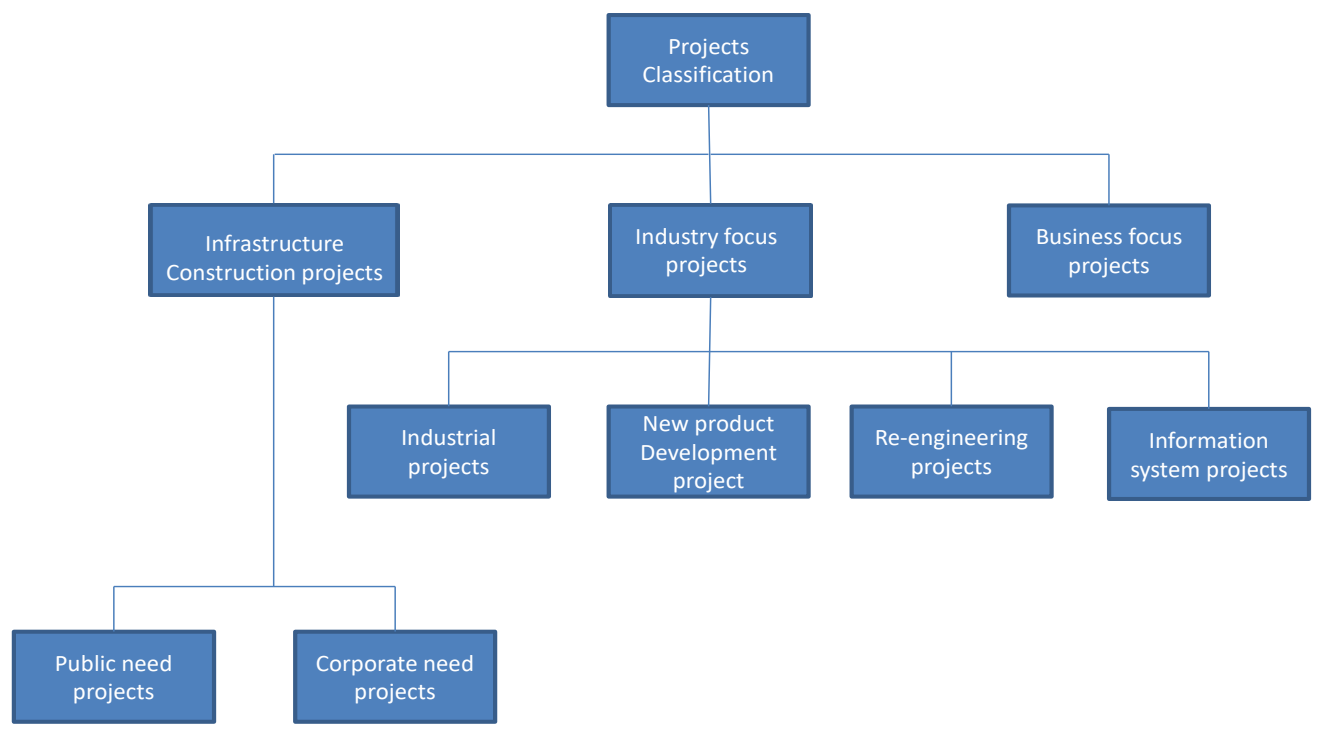

Figure 1: Classification of projects [7]

Figure 1 above shows the classification of projects. First, there are infrastructure construction projects that are normally carried out by government to meet the needs of the public or of business; these are called 'public projects' and 'corporate projects' respectively. Second, there are industry-focused projects that companies in a manufacturing business undertake to introduce a new product or to modify an existing product; such projects can be called 'industrial projects', 'new development projects', 're-engineering projects', or 'information system projects'. Last, there are business-focused projects that are intended to improve company operations [7]. 


\subsubsection{Project management}

Clements and Gido [3] define project management as a tool to plan, organise, coordinate, lead, and control resources to accomplish project objectives. Gray and Larson [5] state that project management can be viewed as a strategic imperative that provides individuals with advanced techniques to improve their ability to organise, execute, and direct certain tasks and events to achieve company goals. Kohli and Chitkara [7] define project management as the application of gained knowledge, skills, tools, and techniques in the project environment in order to achieve the defined project objectives efficiently, effectively, and ethically. This means that project management is about managing project resources authoritatively to achieve certain objectives that are aligned with organisational goals. Therefore, there must be a person who is responsible for planning, organising, coordinating, and leading project resources to execute the project objectives - that is, a project manager.

A project manager is a person who is appointed by the project owner and who has the authority to manage the project resources through planning and controlling [3]. A project manager is also a person who is appointed by the performing company to lead the chosen project team that is responsible for achieving the outlined project goals [6]. Clements and Gido [3] affirm that the responsibility of the project manager is to assure the customer that the defined scope of work will be implemented and finished within the specifications and budget and by the planned completion date. The project manager provides leadership to the project team by coordinating the activities of different team members to ensure that each team member performs the assigned task at the right time to achieve the project objective [3]. This requires a project manager to have certain leadership capabilities in order to demonstrate effective project management skills in their leadership. Clements and Gido [3] state that a project manager is one of the key contributors to ensuring a project's success. Through planning, organizing, and controlling, a project manager has the ability to lead the appointed project team to complete the project by a planned completion date.

Clements and Gido [2] state that project completion is when a contractor has finished all of the work that the works information stipulates be done by the completion date. It should therefore be realised that the project completion date is critical in project management. In fact, Meeamplol and Ogunlan [8] state that time performance is an important factor in all construction projects. The appointed project team must meet and agree on the target completion date for the project [4]. The project completion date is determined by the project team at the project planning meeting. The only way to complete a project by a planned date is by applying project management principles. The project completion date is dependent on the phases of the project lifecycle, which is discussed later [3]. A project team must therefore be mindful of the project lifecycle when determining the project completion date. This will ensure that the project's duration is neither underestimated nor overestimated.

\subsubsection{Project characteristics}

The successful completion of a project to address a specific need can be hindered by many factors, such as scope, cost, and time. These three specific factors are called 'the triple constraints' [3]. It is therefore a duty of the project team to manage all of the factors that can negatively affect the project completion date. Parker, Parsons and Isharyanto [9] state that, in project management, the way to quantify the success of a project is by using the triple constraints.

According to Meeamplol and Ogunlan [8], there is a connection between scope, cost, and time, such that a variation in one factor affects the others. Parker et al. [9] point out that the components of the triple constraints are equally interlinked. In addition, Kohli and Chitkara [7] highlight that project time and cost objectives are inter-connected and that the time factor is the determinant of the project cost. This implies that whenever the project encounters a scope change, cost and time are proportionally affected. Therefore, the proper management of the triple project constraints is vitally important. It is up to the project manager to monitor and control these constraints continuously to ensure that there is no deviation from the plan. Figure 2 illustrates the triple constraints. 


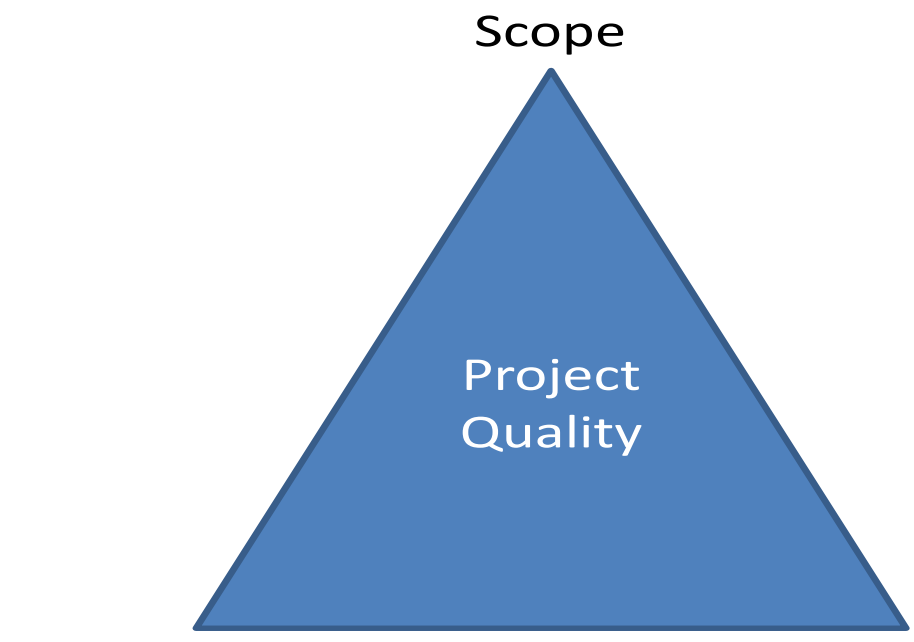

Cost

Time

Figure 2: Triple project constraints [7]

According to Figure 2, there is a direct relationship in project management between cost, time, scope, and quality, and these factors are proportional to one another. This implies that if one factor is changed, other factors will be affected [3]. For example, during project construction, a scope increase will result in a time increase, which will result in a project cost increase. After the scope increase, if the time and costs remain unchanged, the quality will be affected negatively, as the contractor will have to do additional work at a lower cost. The contractor is the person or organisation who has a contract with the client to complete the scope of the identified work [3]. It is therefore vitally important for the client to ensure that the triple constraints are all managed successfully.

\subsubsection{Project organisation structure}

According to Hough, Thompson, Strickland and Cable [10], an organisation is an entity that is designed to achieve certain objectives. Organisations are intended to address certain purposes that are aligned with a company's goals. Burke [11] defines an organisational structure as one that ensures that the company is arranged in a way that will be profitable for the organisation. An organisational structure aims to enable the company to cluster employees in a well-structured way in order to help them to perform their work. Meeamplol and Ogunlan [8] identify three types of project organisational structure that can be used to manage projects, as shown in Figure 3 below.

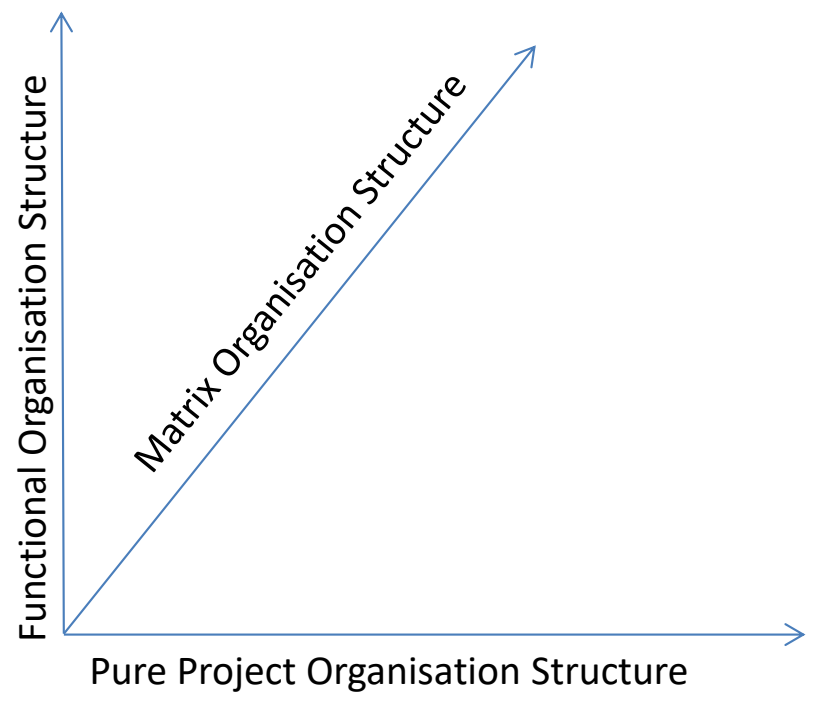

Figure 3: Project organisational structures [11] 
These structures make it possible for the project manager to cut across organisational lines in order to manage the different resources allocated to the project from different departments [37].

\subsection{Trends in factors affecting late delivery of projects}

Meeamplol and Ogunlan [8] studied the factors affecting cost and time performance on highway construction projects, and found that cost and time performances are the measures of project success, meaning that projects completed within cost and time are regarded as successful. They also found that the following factors can reduce time overrun in highway construction projects: improved construction methods, construction resource management, schedule management, human resource management, supervision and control, schedule management, and communication and reporting. According to Ameh and Osegbo [1], poor productivity is one of the factors influencing time overrun in construction sites as a result of a lack of materials, incomplete drawings, and incompetent supervisors.

Ibrahim, Erdogan and Nielsen [12] studied corruption in the Egyptian construction industry, and found that corruption affects the construction industry negatively because it impacts on projects' time, cost, and quality. They emphasised that, when there are elements of corruption in a project, there will be time overruns that cause cost overruns. Chaponda and Allen [13] identified political interference as one of the root causes of the late delivery of projects, and argued that politicians tend to interfere with large projects for personal gain, resulting in time and cost overruns. Consequently, it can be argued that contractors benefit unduly from corruption and political interference since, when projects are delayed, there is generally a cost overrun.

The position is much the same with Eskom's projects: the factors discussed above are the primary causes of time delays in most of its projects, which go to construction without a specific construction method that would lead the project team to investigate the construction method before construction starts. When it comes to resource management, some contractors underutilise the resources allocated to the project owing to a lack of control. Cachalia [14] stated that Eskom has run into many problems, including the late completion of the Medupi power station, because of mismanagement and political interference.

Cachalia [14] added that, by 2011, the schedule for the Medupi build programme was running far behind the original schedule, and the cost of the project had escalated from R80-billion to R120-billion. Anon [15] noted that President Ramaphosa had acknowledged that the factors causing the delays in the construction of the Medupi and Kusile power stations were state capture, corruption, mismanagement, and a shortage of essential skills.

According to Clements and Gido [3], the following factors constrain project success:

1) Underestimation of the cost of the materials;

2) Excessive weather conditions;

3) Additional scope modifications in order to meet specifications and testing requirements;

4) Late delivery of critical materials; and

5) Incompetence of key project members.

In addition, Ameh and Osegbo [1] identified the following major causes of time overruns in projects:

1) Insufficient planning of project before starting;

2) Delay in the delivery of materials;

3) Design changes during project implementation;

4) Sub-contractor incompetence;

5) Delays in responding to decision-making; and

6) Temporary stoppages owing to inclement weather.

In their study, Meeamplol and Ogunlan [8] identified the following factors that hindered time performance in the delivery of highway construction projects in Thailand:

1) Design effectiveness;

2) Schedule management;

3) Budget management;

4) Construction method;

5) Human resource management; and

6) Team relationships. 
This study aimed to determine the internal and external factors influencing the delivery of projects at Eskom. It adopted a quantitative method. Data for the research was obtained from both primary and secondary sources. A well-structured questionnaire, based on information obtained from the reviewed literature, was distributed to project engineers, project managers, project coordinators, project controllers, project buyers, clerk of works, contract managers, and quantity surveyors.

Data collection was done through self-administered questionnaires sent to one hundred participants who were Eskom employees (managers and staff), consultants, and contractors. The questionnaire had 72 questions in total, all of which were closed-ended questions that are framed in such a way that the study's objectives were achieved.

The questionnaire had three main sections. The first collected data relating to the respondent's category, highest level of education, department of work, age group, gender, and number of years in the project management environment. The information sought in this section was important to contextualising the data provided in the second and third sections. The second section was aimed at examining whether Eskom's project lifecycle model was in line with the project management project lifecycle as outlined in the project management body of knowledge. It also gathered the participants' knowledge of project completion and of the key role players in driving the project. The third section aimed to assist the participants to identify the factors, and the primary causes of those factors, that resulted in the late delivery of projects at Eskom.

A non-random sampling method was used to select participants in the Eastern Cape Province who were employees of Eskom, consultants, construction firms, construction managers, and quantity surveyors. They were chosen because of their active involvement in the value chain of project development and execution in the state-owned enterprises environment.

\section{ANALYSIS OF RESULTS}

The analysis of the results was based on the information gathered from all of the Eskom employees (managers and staff) and from consultants and contractors. The participants were asked to rate the levels of the internal and external factors that influenced the late delivery of construction projects at Eskom.

The data were classified and analysed using the relative importance index (RII) tool on the internal and external factors influencing the late delivery of projects. The method was adopted because it had been used in a previous study [8]. The relative importance index determines the importance of various internal and external factors affecting the late delivery of projects. The results of the RII analysis are shown in Table 1 below.

Table 1: Field survey showing the results of the RII analysis

\begin{tabular}{|c|c|c|c|c|c|}
\hline No. & Factors & $\begin{array}{l}\text { Total } \\
\text { respondents }(\mathrm{N})\end{array}$ & $\begin{array}{l}\text { Weighted } \\
\text { total }\end{array}$ & RII & $\begin{array}{l}\text { Item } \\
\text { mean }\end{array}$ \\
\hline \multicolumn{6}{|c|}{ Factors related to excessive weather conditions } \\
\hline 1 & $\begin{array}{l}\text { Poor planning (planning for adverse weather } \\
\text { conditions to ensure that other activities can be } \\
\text { done during bad weather) }\end{array}$ & 102 & 344 & 0.675 & 3.373 \\
\hline 2 & Scheduling for bad weather & 102 & 339 & 0.665 & 3.324 \\
\hline \multicolumn{6}{|c|}{ Factors related to underestimation of cost of material } \\
\hline 3 & Additional project scope & 102 & 431 & 0.845 & 4.225 \\
\hline 4 & Poor estimation of material & 102 & 420 & 0.824 & 4.118 \\
\hline 5 & Increase in material costs during construction & 102 & 387 & 0.759 & 3.794 \\
\hline \multicolumn{6}{|c|}{ Factors related to delivery of material } \\
\hline 6 & Late delivery of Eskom stock material & 102 & 384 & 0.753 & 3.765 \\
\hline 7 & Late delivery of Eskom non-stock material & 102 & 370 & 0.725 & 3.627 \\
\hline 8 & Late delivery of contractor-supplied material & 102 & 319 & 0.625 & 3.127 \\
\hline \multicolumn{6}{|c|}{ Factors related to crucial material } \\
\hline 9 & Late submission of bill of material & 102 & 236 & 0.463 & 2.314 \\
\hline 10 & Low stock holdings by Eskom stores & 102 & 255 & 0.500 & 2.500 \\
\hline 11 & Delays in placing purchase orders & 102 & 396 & 0.776 & 3.882 \\
\hline 12 & Suppliers not meeting committed dates & 102 & 381 & 0.747 & 3.735 \\
\hline 13 & Rotran not collecting Eskom material on time & 102 & 348 & 0.682 & 3.412 \\
\hline
\end{tabular}




\begin{tabular}{|c|c|c|c|c|c|}
\hline 14 & Late delivery of contractor-supplied material & 102 & 324 & 0.635 & 3.176 \\
\hline \multicolumn{3}{|c|}{ Factors related to management plans } & \multicolumn{3}{|c|}{ Total average: 0.792} \\
\hline 15 & Scope management plan & 102 & 412 & 0.808 & 4.039 \\
\hline 16 & Schedule management plan & 102 & 404 & 0.792 & 3.961 \\
\hline 17 & Procurement management plan & 102 & 395 & 0.775 & 3.873 \\
\hline \multicolumn{3}{|c|}{ Factors related to sub-contractor incompetence } & \multicolumn{3}{|c|}{ Total average: $\mathbf{0 . 7 3 6}$} \\
\hline 18 & Past work experience & 102 & 373 & 0.731 & 3.657 \\
\hline 19 & Qualification (authorizations, including H.V. regs) & 102 & 366 & 0.718 & 3.588 \\
\hline 20 & Insufficient resources & 102 & 380 & 0.745 & 3.725 \\
\hline 21 & Insufficient tools and equipment & 102 & 383 & 0.751 & 3.755 \\
\hline \multicolumn{6}{|c|}{ Factors related to delay in responses to decision-making $\quad$ Total average: 0.778} \\
\hline 22 & Project manager & 102 & 433 & 0.849 & 4.245 \\
\hline 23 & Clerk of works & 102 & 385 & 0.755 & 3.775 \\
\hline 24 & Project engineer & 102 & 440 & 0.863 & 4.314 \\
\hline 25 & Contracts manager (contractor) & 102 & 372 & 0.729 & 3.647 \\
\hline 26 & Site supervisor (contractor) & 102 & \multirow{2}{*}{\multicolumn{3}{|c|}{ Total average: 0.796}} \\
\hline \multicolumn{3}{|c|}{ Factors related to poor schedule management } & & & \\
\hline 27 & Progress meetings not being held regularly on site. & 102 & 394 & 0.773 & 3.863 \\
\hline 28 & Poor construction programme & 102 & 420 & 0.824 & 4.118 \\
\hline 29 & Contractor not submitting progress reports & 102 & 402 & 0.788 & 3.941 \\
\hline 30 & $\begin{array}{l}\text { Project manager not updating construction } \\
\text { programme }\end{array}$ & 102 & 407 & 0.798 & 3.990 \\
\hline \multicolumn{3}{|c|}{ Factors related to constructability plan } & \multicolumn{3}{|c|}{ Total average: 0.859} \\
\hline 31 & $\begin{array}{l}\text { In Eskom projects, unclear constructability plan } \\
\text { contributes to late delivery of projects as a result of } \\
\text { lack of planning. }\end{array}$ & 102 & 438 & 0.859 & 4.294 \\
\hline \multicolumn{3}{|c|}{ Factors related to lack of training } & \multicolumn{3}{|c|}{ Total average: $\mathbf{0 . 7 6 5}$} \\
\hline 32 & Project manager & 102 & 390 & 0.765 & 3.824 \\
\hline 33 & Project engineer & 102 & 416 & 0.816 & 4.078 \\
\hline 34 & Clerk of works & 102 & 405 & 0.794 & 3.971 \\
\hline 35 & Contract manager & 102 & 367 & 0.720 & 3.598 \\
\hline 36 & Site supervisor & 102 & 374 & 0.733 & 3.667 \\
\hline \multicolumn{3}{|c|}{ Factors related to final design package } & \multicolumn{3}{|c|}{ Total average: $\mathbf{0 . 8 2 7}$} \\
\hline 37 & $\begin{array}{l}\text { Work load in network engineering development } \\
\text { (NED). }\end{array}$ & 102 & 412 & 0.808 & 4.039 \\
\hline 38 & $\begin{array}{l}\text { Late approvals required for Final Design Package } \\
\text { (environmental impact assessment, wayleaves, and } \\
\text { land acquisition) }\end{array}$ & 102 & 432 & 0.847 & 4.235 \\
\hline \multicolumn{3}{|c|}{ Factors related to lack of project leadership } & \multicolumn{3}{|c|}{ Total average: 0.804} \\
\hline 39 & Poor leadership ability & 102 & 412 & 0.808 & 4.039 \\
\hline 40 & Lack of communication skills & 102 & 413 & 0.810 & 4.049 \\
\hline 41 & Poor time management skills & 102 & 408 & 0.800 & 4.000 \\
\hline 42 & Poor problem-solving skills & 102 & 408 & 0.800 & 4.000 \\
\hline \multicolumn{3}{|c|}{ Factors related to stakeholder identification } & \multicolumn{3}{|c|}{ Total average: $\mathbf{0 . 8 1 2}$} \\
\hline 43 & $\begin{array}{l}\text { In Eskom projects, lack of identification of key } \\
\text { project stakeholders contributes to late delivery of } \\
\text { projects }\end{array}$ & 102 & 414 & 0.812 & 4.059 \\
\hline \multicolumn{3}{|c|}{ Factors related to scope creep } & \multicolumn{3}{|c|}{ Total average: $\mathbf{0 . 8 7 6}$} \\
\hline 44 & $\begin{array}{l}\text { In Eskom projects, scope creep (design change } \\
\text { requests) contributes to late delivery of projects }\end{array}$ & 102 & 447 & 0.876 & 4.382 \\
\hline \multicolumn{3}{|c|}{ Factors related to outage bookings } & \multicolumn{3}{|c|}{ Total average: $\mathbf{0 . 8 6 2}$} \\
\hline 45 & Late booking of outages & 102 & 409 & 0.802 & 4.010 \\
\hline 46 & Late approval of outages & 102 & 461 & 0.904 & 4.520 \\
\hline 47 & Incorrect single line diagram (SLD) & 102 & 449 & 0.880 & 4.402 \\
\hline
\end{tabular}

Around $28 \%$ of the participants argued that poor scheduling did not affect the timely delivery of projects, but that lack of proper scheduling for bad weather causes work to stop completely when there is heavy rain or bad weather; and this affects the pace at which the project progresses. Ameh and Osegbo [1] found that temporary stoppages because of inclement weather can affect projects.

Around $53 \%$ of the participants argued that the failure to cater for additional project scope resulted in the late delivery of projects. Only $18 \%$ of the participants disagreed with this. This showed that the failure to plan for unforeseen circumstances results in late delivery. 
Around $45 \%$ of the participants agreed, and $36 \%$ strongly agreed, that the poor estimation of materials contributed to the late delivery of projects. Less than $7 \%$ of the participants disagreed with this, showing that most of the participants believed that the poor estimation of materials resulted in projects being finished late.

Only $14 \%$ of the participants disagreed that increases in costs during construction led to the late delivery of projects. Increases in the cost of materials can cause suppliers to delay delivering the required materials when they are not paid. When material prices increase unexpectedly, the budget becomes constrained, and there might be a shortage of funds; and this too delays the completion of the project.

About $17 \%$ of the participants disagreed that poor scope management planning resulted in the late delivery of projects. Burke [11] stated that project scope management is one the knowledge areas indicated in the project management body of knowledge that enable the project manager to ensure that the project scope of work includes all of the work required to achieve the project goals. Burke [11] added that scope management is one of the key areas that indicate project success, and that the failure to identify the project scope will produce unwanted results leading to implications for time, cost, and quality.

About $73 \%$ of the participants believed that poor procurement management planning was a contributing factor to the late delivery of projects at Eskom. Meeamplol and Ogunlan [8] found that improved construction methods, construction procurement management, and schedule management could reduce time overruns in highway construction projects.

About $86 \%$ of the participants believed that the poor design of a construction programme resulted in the late delivery of projects. Only $4 \%$ of the participants disagreed.

Almost $72 \%$ of the participants believed that the contractor's failure to submit progress reports resulted in the late delivery of projects. Only $13 \%$ of the participants disagreed with this, stating that they did not believe that the failure of the contractor to submit progress reports resulted in the late delivery of projects.

An overwhelming $87 \%$ of the participants believed that late delivery could be partly attributed to the construction manager failing to update the construction programme. Only $2 \%$ of the participants disagreed with this.

Based on the results presented in Table 1, derived from the relative importance index analysis, the internal factors have been shown proven to be the leading ones influencing the late delivery of projects.

The following internal factors had the highest relative importance index:

- $\quad$ Outage bookings (relative importance index 0.862)

- $\quad$ Scope creep (relative importance index 0.876)

- $\quad$ Lack of identification of key project stakeholders (relative importance index 0.812 )

- $\quad$ Lack of project leadership (relative importance index 0.804 )

- $\quad$ Finalisation of design package (relative importance index 0.827 )

Studies conducted by Clements and Gido [3] and Meeamplol and Ogunlan [8] identified the various factors that influenced the late delivery of projects in the construction industry. It was evident that state-owned enterprises were not exempt from these factors. External factors proved not to be dominant in resulting to the late delivery of projects in Eskom.

The following external factor had the high relative importance index:

- Incompetence of sub-contractors (relative importance index 0.736)

\subsection{Summary of findings from the literature and field work}

The results showed that a number of factors contribute to the late delivery of projects. Factors such as poor planning, underestimating the cost of the materials, excessive weather conditions, additional and scope modifications in order to meet specifications and testing requirements, the late delivery of critical materials, and the incompetence of key project members lead to late delivery. Some of the findings are as follows:

1) Most of the participants believed that the failure by the project manager to update the construction programme resulted in the late delivery of projects. 
2) Most of the participants agreed that the failure by the contractor to submit progress reports resulted in the late delivery of projects.

3) Most of the participants believed that, in Eskom projects, poor schedule management contributed to the late delivery of projects as the result of a poor construction programme.

4) Most of the participants believed that poor procurement management planning resulted in the late delivery of projects.

5) Most of the participants agreed that a poor schedule management plan resulted in the late delivery of projects.

6) Most of the participants agreed that, in Eskom projects, poor drafting of the scope management plan contributed to the late delivery of projects.

7) Most participants agreed that the late delivery of contractor-supplied materials was one of the factors that contributed to the late delivery of projects.

8) The study also found from the literature that mega-projects are heavily affected by corruption, interference by politicians, and mismanagement.

\section{CONCLUSION AND RECOMMENDATION}

This study determined the perceptions of state-owned enterprises employees, contractors, and consultants of the internal and external factors influencing the late delivery of projects at Eskom. The findings indicate that the top three internal factors were the project manager not updating the construction schedule, poor procurement management, and poor drafting of the scope management plan. The top two external factors were the late delivery of contractor-supplied materials, and the failure to submit progress reports. Adverse weather conditions were identified as one of the external factors, although they were not rated high by the participants. The literature identified that political interference, mismanagement, and corruption had a major influence on the late delivery of projects at Eskom, especially its mega-projects.

The study recommends that state-owned enterprises ensure that there are proper development programmes to train the project team on project deliverables. This would equip the project team to fulfill its project duties. State-owned enterprises should appoint qualified and experienced principal contractors with a good reputation in the construction of projects. State-owned enterprises' procurement management processes should be revised to ensure that they support the early completion of projects. Project managers must plan for extreme weather conditions, and such days must be incorporated into the project schedule. State-owned enterprises must give a project team, through the project manager, a full delegation of authority to manage the project, as this would be in line with project management principles. This would ensure that the project manager took rapid decisions that would assist in the smooth running of the project, thus eliminating possible delays that would affect project completion.

Government should reconfigure the current policy framework on state-owned enterprise management, such that politicians are not allowed to interfere in the project execution value chain. Government needs to deal decisively with acts of corruption by imposing severe sanctions on those businesses and individuals who are involved in such acts. These interventions should reduce corruption significantly, especially in the construction of mega-projects, while also eliminating delays in project completion. Finally, state-owned enterprise employees, along with the contractors and consultants who are involved in the project execution value chain, should embark on a collective, proactive, and continuous drive to report and fight corruption and mismanagement in project management practices.

\section{ACKNOWLEDGEMENT}

This research was supported by the Durban University of Technology Research Grant, 2020.

\section{REFERENCES}

[1] Ameh, O. and Osegbo, E. 2011. Study of relationship between time overrun and productivity on construction sites. International Journal of Construction Supply Chain Management, vol. 1(1). Available from: http://eprints.covenantuniversity.edu.ng/3192/1/Ameh\%20\%26\%200segbo\%202011.pdf [Accessed 27 April 2015].

[2] Clements, J. and Gido, J. 2012. Effective project management. 5th edition. Melbourne, Australia: South-Western.

[3] ESKOM. 2012. Eskom's third revenue and tariff application. Unknown. Eskom. Available from: https://static.pmg.org.za/docs/121121submission.pdf [Accessed 22 May 2015]

[4] ESKOM. 2011. Capital investment process in the distribution business. Unknown: Eskom. Available from: http://www.eskom.co.za/OurCompany/Investors/IntegratedReports/Documents/Interim_results_30_Sept_2011_ media_presentation_final2.pdf [Accessed 15 May 2015] 
[5] Gray, C. and Larson, E. 2008. Project management: The managerial process. 4th edition. New York: McGrawHill/Irwin.

[6] Project Management Institute. 2013. A guide to the project management body of knowledge. 5th edition. Newtown Square, Pennsylvania: Project Management Institute.

[7] Kohli, U. and Chitkara, K.K. 2007. Project management handbook: For engineers, construction professionals and business managers. New Delhi, India: Tata McGraw-Hill

[8] Meeamplol, S. and Ogunlan, S.0. 2006. Factors affecting cost and time performance on highway construction projects: Evidence from Thailand. Journal of Financial Management of Property and Construction, vol. 11(1), pp. 3-20. Available from: http://dx.doi.org/10.1108/13664380680001076 [Accessed 19 April 2015].

[9] Parker, D.W., Parsons, N. and Isharyanto, F. 2015. Inclusion of strategic management theories to project management. International Journal of Managing Projects in Business, 8(3), pp. 552-573. Available from: https://www.emerald.com/insight/content/doi/10.1108/IJMPB-11-2014-0079/full/html [Accessed 15 June 2016].

[10] Hough, J., Thompson, A.A., Strickland, A.J. and Cable, J.E. 2007. Crafting and executive strategy. South African 2nd edition. Boston: McGraw-Hill.

[11] Burke, R. 2013. Project management techniques. 2nd edition. Hong Kong, China: Burke Publishing.

[12] Ibrahim, A.H., Erdogan, B. and Nielsen, Y. 2019. Corruption in the Egyptian construction industry. Conference paper. Available from:

https://www.researchgate.net/publication/336025163_Corruption_in_the_Egyptian_Construction_Industry [Accessed 23 August 2020].

[13] Chaponda, T. and Allen, R. 2019. Political interference and infrastructure governance. Available from: https://blog-pfm.imf/org/pfmblog/2019/04/political-interference-and-infrastructure-governance.html [Accessed 24 August 2020].

[14] Cachalia, G. 2020. Can Eskom be saved? Daily Maverick, 14 January: 1. Available from: https: / /www.dailymaverick.co.za/opinionista/2020-01-14-can-eskom-be-saved/ [Accessed 20 June 2020].

[15] City Press Staff Reporter. 2019. Medupi is a fitting symbol of the importance of our SOEs - Ramaphosa. City Press, 09 December 2019. Available from: https://www.news24.com/citypress/news/medupi-is-a-fitting-symbol-of-theimportance-of-our-soes-ramaphosa-20191209 [Accessed 20 June 2020]. 